\title{
The impacts of national and local government actions on active travel
}

\author{
Jennifer S. Mindell
}

Earlier this year, I was lucky enough to witness the weekly 'Ciclovía' in Bogotá, Colombia. Main roads are open to people and closed to traffic for several kilometres on one side of the dual carriageway [main road with a central barrier] every Sunday and public holidays from 07:00 until 14.00; motor vehicles are replaced by people walking, jogging, cycling, skateboarding, or rollerblading in a twoway stream. People of all ages take part in the weekly event, travelling at a wide range of speeds but with no apparent friction or conflicts. Currently more than 300 cities in the Americas have implemented similar programmes but the one in Bogotá is the largest (Sarmiento et al., 2010). Since it started in 1974, the route has gradually expanded to $121 \mathrm{~km}$ (76 miles), with about 600,000 to $1,400,000$ people taking part each week (Díaz-del-Castillo et al., 2011). It has been supported by successive Mayors, who have also supported Cicloruta, a network of bicycle paths (Torres et al., 2013).

Government policies on planning and transport infrastructure have major impacts on travel modes (Bhalla, 2013). This is important not only for health reasons but also for sustainability and climate change mitigation - or exacerbation (Frank et al., 2010). High income countries range from those with an embedded cycling culture that has been actively encouraged, such as the Netherlands and Denmark (Pucher and Buehler, 2008 and Wardlaw, 2014) to those with low cycling rates, such as the UK and the USA (McKenzie, 2014, Pucher and Buehler, 2008 and Wardlaw, 2014). Walking and cycling rates also vary substantially within countries (e.g. the USA (McKenzie, 2014)), dependent not only on distances but by regional and local government policies and actions.

A UK Department for Transport report in 2013 considered mainstreaming non-motorised travel as 'a cost-effective way to relieve congestion and improve the quality of life', with increased levels of nonmotorised travel used as a tool to stronger, better-linked communities, healthcare savings, improved accessibility for disadvantaged groups, more attractive public spaces, and an attractor for new businesses (DfT, 2013). However, in June 2014, the UK Government published its Infrastructure Bill ${ }^{1}$, focussing (in relation to transport) solely on road building, despite the evidence showing that increasing capacity induces more motorised traffic (SACTRA, 1994), while road capacity reduction in the longer term reduces motorised traffic (Goodwin et al., 1998 and Kruse, 1998). Benefits of road building have historically been overestimated (SACTRA, 1994); while there are some benefits to employment (Gibbons et al., 2012), the financial benefits are small compared with the costs, and some may be displacement from one area to another, rather than net gains (Sanchis-Guarner, 2013).

The potential negative impacts of the Bill were mitigated when an amendment was accepted that forms part of the Act, requiring the Secretary of State for Transport to publish a strategy for walking and cycling infrastructure and to provide the funding for these (UK Government, 2015 ). While not as ground-breaking as the 2013 Welsh Active Travel Act (National Assembly for Wales, 2013), which requires "the Welsh Ministers and local authorities to ... enhance the provision made for, and to have regard to the needs of, walkers and cyclists; [and] ... to promote active travel journeys and secure new and improved active travel routes and related facilities", it is still a welcome step forward.

This current dominance of streets by motorised vehicles is a historically recent phenomenon. The narrow, cobblestoned streets and roads in many older European cities, particularly within the

\footnotetext{
${ }^{1}$ In the UK, draft legislation is called a Bill while being discussed and an Act once it is passed into law.
} 
central, walled parts, bear witness to a time before motor vehicles. However, lower income countries where walking and cycling have been dominant forms of travel are now struggling to maintain this in the face of rising car and motorised two-wheeler ownership. In China, pavements [sidewalks] and segregated cycle lanes, previously required by law, are being replaced by car parks as road space is reallocated to motor vehicles (Day et al., 2013). In India, rapid rises in ownership of motorised two-wheelers and private cars is associated with reductions in active travel and high fatality rates among non-motorised travellers (Singh, 2005 and Srinivasan et al., 2007). Such changes are likely to have negative implications for public health, not only because of injuries, and indeed sustainability and global climate change (Chapman, 2007 and Mindell et al., 2011), but also because of the well known benefits of physical activity. Although only a cross-sectional survey, a strong association has also been found in India between active travel and lower cardiovascular risks (Millet et al., 2013).

Public bicycle sharing schemes continue to increase in number and size. Interestingly, China has the largest numbers of such schemes (Bhalla, 2013). So far, few studies have been published that consider their impacts on the users and/or the community. An early attempt at assessing the net health effects for users (Rojas-Rueda et al., 2011) has been criticised for overestimating the extent to which bikeshare journeys replaced motor vehicle journeys (Fishman, 2011). Fishman (2015) have calculated the net increase in physical activity in cities around the world that have implemented public bikeshare schemes. Significant though this additional activity is, however, it may be that the role of bikeshare schemes to normalise others' views of cycling and cyclists is equally important (Fishman, 2011, Rojas Rueda et al., 2011 and Goodman et al., 2014).

The health impacts of Ciclovía include benefits from increased physical activity for participants, with a cost:benefit ratio above three (Montes et al., 2012 and Sarmiento et al., 2010) with additional health benefits for the community from reduced air and noise pollution (Sarmiento et al., 2010 and Torres et al., 2013). I was fascinated by the change in my perception of Ciclovía when I moved from walking along the pavement [sidewalk] to walking in the road with the other participants: moving a few metres to be in rather than alongside the stream of 'traffic' changed me from being an observer to a participant, despite my actual movement being identical. This may be one aspect of 'fun' referred to by Romero (2015) in an account of children's perceptions of their commute in this issue of the journal. Another may be the planned and opportunistic social encounters that ensue when people use public spaces without being confined within private cars; even the marked social class differences that divide Colombian society appear to fade within Ciclovía, with participants reporting greater social capital (Torres et al., 2013).

In addition to the direct effects of the weekly physical activity, it is also important to assess the effects of both weekly events such as Ciclovía and annual car-free days, held in cities around the world in late September, on longer term changes in travel behaviour and attitudes. Do participants gain sufficient confidence and fitness that they then use active travel modes for journeys, not just for leisure?

Active travel is desirable for people at any age. Oxford and Pollock (2015) report on active travel of young children aged two to four years to their pre-school. They found widely differing rates, with a number of factors, including weather and distance, independently associated with active travel. Among older people, e-bikes have the potential to extend the age at which people can continue to cycle. This issue also contains themed sections with further papers on both older people's travel and transport (see Musselwhite, 2015), and the geographies of active travel (see Alvanides, 2015).

Accompanying this general issue of the journal is a supplement that contains the abstracts accepted for presentation at the 1st International Conference on Transport and Health. These are preceded by an editorial about the conference that also explains our Virtual Special Issue (Mindell, 2015). The online submission system for this journal has been amended and now includes the option to submit letters for publication. We look forward to receiving your comments. 


\section{References}

Alvanides S. Themed section on the geographies of active travel (Editorial). J. Transp. Health, 2 (2) (2015), pp. 97-98.

Bhalla K. The health effects of motorization. PLoS Med., 10 (6) (2013), p. e1001458. http://dx.doi.org/10.1371/journal.pmed.1001458

Chapman L, (2007) Transport and climate change: a review. J. Transp. Geogr., 15 (2007), pp. 354367.

Day K, Alfonzo M, Chen Y,. Guo Z, Lee KK. Overweight, obesity and inactivity and urban design in rapidly growing Chinese cities. Health Place, 21 (2013), pp. 29-38.

Department for Transport. City Deals - Guidance on Applications for Cycle City Ambition Grants [online]. Available from:

https://www.gov.uk/government/uploads/system/uploads/attachment data/file/83002/cycle-cityambition-grant-guidance.pdf .

Díaz-del-Castillo A., O.L. Sarmiento, R. Reiss, R. Brownson. Translating evidence to policy: Urban interventions and physical activity promotion in Bogotá, Colombia and Curitiba, Brazil. Transl. Behav. Med., 1 (2) (2011), pp. 350-360

Fishman E. Evaluating the benefits of public bicycle schemes needs to be undertaken carefully. BMJ, 343 (2011), p. d4521.

Fishman E. Bikeshare's impact on active travel: evidence from the United States, Great Britain, and Australia. J. Transp. Health, 2 (2) (2015), pp. 135-142.

Frank LD, M.J. Greenwald, S. Winkelman, J. Chapman, S. Kavageb. Carbonless footprints: promoting health and climate stabilization through active transportation. Prev. Med., 50 (Suppl. 1) (2010), pp. S99-S105.

Gibbons, S., Lyytikäinen, T., Overman, H., Sanchis-Guarner, R., 2012. New road infrastructure: the effects on firms. SERC Discussion paper 117. London: UK Spatial Economics Research Centre, London School of Economics and Political Science.

www.spatialeconomics.ac.uk/textonly/serc/publications/download/sercdp0117.pdf (accessed 27.03.15).

Goodman A, J. Green, J. Woodcock. The role of bicycle sharing systems in normalising the image of cycling: an observational study of London cyclists. J. Transp. Health, 1 (1) (2014), pp. 5-8.

Goodwin PB, C. Hass-Klau, S. Cairns. Evidence of the effects of road capacity reduction on traffic levels. Traffic Eng. Control, 39 (6) (1998), pp. 348-354.

Kruse, J., 1998. Remove it and they will disappear. Progress, published by Surface Transportation Policy Project. http://ntl.bts.gov/lib/1000/1100/1165/00778490.pdf (accessed 27.03.15).

McKenzie, B., 2014. Modes less traveled-bicycling and walking to work in the United States: 20082012. American Community Survey Reports. U.S. Census Bureau. www.census.gov/prod/2014pubs/acs-25.pdf (accessed 27.03.15).

Millet C, S. Agrawal, R. Sullivan, M. Vaz, A. Kurpad, D. Prabhakaran, A.V. Bharathi. Associations between active travel to work and overweight, hypertension, and diabetes in India: a cross-sectional study. PLoS Med., 10 (6) (2013), p. e1001459 http://dx.doi.org/10.1371/journal.pmed.1001459

Mindell JS, J.M. Cohen, S. Watkins, N. Tyler. Synergies between low carbon and healthy transport policies. Proc. Inst. Civil Eng. Transp., 164 (2011), pp. 127-139.

Mindell, JS. 1st International Conference on Transport and Health (ICTH 2015). J. Transp. Health. vol 2 (Supplement to issue 2): S1-S2. 
Montes F, O.L. Sarmiento, R. Zarama, M. Pratt, G. Wang, E. Jacoby, T. Schmid, M. Ramos, O. Ruiz, O. Vargas, G. Michel, S. Zieff, J.A. Valdivia, N. Cavill, S. Kahlmeier. Do the benefits outweigh the costs?: an economic analysis of four international mass recreational programs. J. Urban Health, 89 (1) (2012), pp. 153-170.

Musselwhite CBA. Further examinations of mobility in later life and improving health and wellbeing (Editorial). J. Transp. Health, 2 (2) (2015), pp. 99-100.

National Assembly for Wales (2013). Active Travel (Wales) Act 2013. www.legislation.gov.uk/anaw/2013/7/contents/enacted (accessed 27.03.15).

Oxford L, J. Pollock. How actively do children travel to their pre-school setting? J. Transp. Health, 2 (2) (2015), pp. 151-159.

Pucher J, R. Buehler. Making cycling irresistible: lessons from The Netherlands, Denmark and Germany. Transp. Rev., 28 (2008), pp. 495-528 http://dx.doi.org/10.1080/01441640701806612

Rojas Rueda D, A. de Nazelle, M. Tainio, M. Nieuwenhuijsen. The health risks and benefits of cycling in urban environments compared with car use: health impact assessment study. BMJ, 343 (2011), p. d4521

Romero V. Children's experiences: enjoyment and fun as additional encouragement for walking to school. J. Transp. Health, 2 (2) (2015), pp. 230-237

SACTRA (1994). Standing Advisory Committee on Trunk Road Assessment (Woods, D Chair). Trunk Roads and the Generation of Traffic. London: Department for Transport.

http://webarchive.nationalarchives.gov.uk/+/http:/www.dft.gov.uk/pgr/economics/rdg/nataarchive docs/trunkroadstraffic.pdf (accessed in 2015).

Sanchis Guarner, R., 2013. On the road to recovery? London: UK Spatial Economics Research Centre, London School of Economics and Political Science. http://spatialeconomics.blogspot.co.uk/2013/06/on-road-to-recovery.html (accessed 27.03.15).

Sarmiento O, A. Torres, E. Jacoby, M. Pratt, T. Schmid, G. Stierling The Ciclovía-recreativa: a mass recreational program with public health potential. J. Phys. Act. Health, 7 (Suppl. 2) (2010), pp. S163S180

Singh AK. Review of Urban transportation in India. J. Public Transp., 8 (1) (2005), pp. 79-97

Srinivasan KK, P.V. Lakshmi Bhargavi, G. Ramadurai, V. Muthuram, S. Srinivasan. Determinants of changes in mobility and travel patterns in developing countries. Case study of Chennai, India. Transp. Res. Rec.: J. Transp. Res. Board (2038) (2007), pp. 42-52 http://dx.doi.org/10.3141/2038-06

Torres A, O.L. Sarmiento, C. Stauber, R. Zarama. Ciclovia and Cicloruta programs: promising interventions to promote physical activity and social capital in Bogotá. Am. J. Public Health, 103 (2) (2013), pp. e23-e30.

UK Government (2015). Infrastructure Act 2015. http://services.parliament.uk/bills/201415/infrastructure.html (accessed 27.03.15).

Wardlaw MJ. History, risk, infrastructure: perspectives on bicycling in the Netherlands and the UK (Review article). J. Transp. Health, 1 (4) (2014), pp. 243-250 